\title{
A Literary Review on Role of Vidalaka in Eye Disorders
}

\author{
Sangram Singh Rajput ${ }^{1}$, Shiromani Mishra ${ }^{2}$, Ravindra Sharma ${ }^{3}$, \\ Shikha Sharma ${ }^{4}$ \\ ${ }^{1}$ P.G.Scholar, Department of Dravyaguna Vigyan, Govt. Dhanwantari Ayurved College, Ujjain (M.P.). \\ ${ }^{2}$ Reader, Department of Dravyaguna Vigyan, Govt. Dhanwantari Ayurved College, Ujjain (M.P.). \\ ${ }^{3}$ Lecturer, Department of Dravyaguna Vigyan, Govt. Dhanwantari Ayurved College, Ujjain (M.P.). \\ ${ }^{4}$ P.G. Scholar, Department of Shalakya Tantra, National Institute of Ayurveda, Jaipur (Raj.)
}

Corresponding Author: Sangram Singh Rajput

\begin{abstract}
Shalakya Tantra is one of the most unique branches of Ayurveda dealing with disorders of all supraclavicular regions. Apart from all these region eye possess prime importance as they are the gateway to the external world. Netra is said to be the Pradhana Indriya and to protect the eye sight should be the prime objective. Without the eyes the whole world appears black and one depends on others for the lifetime. There are 94 eye disorders mentioned in Ayurveda text this can cause many sympaoms from minute itching in eyes upto even complete loss of vision. In managing these ocular diseases Acharyas have mentioned various local and systemic measures. Kriyakalpa is one of the therapy in treatment of Netra Gata Rogas. Vidalaka is one of the Kriyakalpa procedure used in eye disorders.
\end{abstract}

Keywords: Vidalaka, Netra Gata Roga, Sarva Netra Rogahara Vidalaka

\section{INTRODUCTION}

Kriyakalpa is the most distinct branch of Shalakya Tantra. Acharya Sushruta has mentioned five types of Kriyakalpa i.e., Tarpana, Putapaka, Seka, Ashcyotana \& Anjana. Apart from these five Sharangdhar has included Pindi \& Vidalaka. Vidalaka is one of the types of Lepa Kalpana. It is used in acute ocular conditions. ${ }^{1}$ It is used in condition of Daha (burning sensation), Updeha (stickyness), Ashrusrava (watering), Shopha (oedema) \& Raga (congestion) in the eyes.

A semisolid paste of drugs is applied around the eyes leaving the eyelashes is called as Vidalaka. ${ }^{2}$

\section{Aims \& objective:}

1. To provide detailed description of Vidalaka given in Ayurvedic Samhitas.
2. To mention the drugs that can be applied in the form of Vidalaka in various ocular disorders.

3. To understand the mode of action of Vidalaka Karma.

\section{MATERIALS \& METHOD \\ Time of administration:}

Vidalaka can be applied at any time of the day or whenever the symptoms are exaggerating. ${ }^{3}$

\section{Vidhi:}

The medicines are made into a fine paste. Then eyes are cleaned with luke warm water and paste is applied over the closed eyes leaving the area of eye lashes. After that it is washed with warm water before or after drying depending upon the condition. 
Dose:

As Vidalaka is a type of Lepa Kalpana, which is considered as an initial Chikitsa of Vrana Shotha. The amount of Vidalaka is same as the dose of Mukha Lepa-

$1 / 4$ th of the thickness of thumb- Kanistha Matra

$1 / 3$ rd of the thickness of the thumbMadhyama Matra

$1 / 2$ nd of the thickness of the thumb- Uttama Matra
It is removed before it gets dried because after drying it loses its properties.

After Vidalaka is applied following things are contraindicated-

Sleeping during day time, being in sunlight for a long time and excessive speaking, laughing, weeping etc. ${ }^{4}$ If these measures are not followed it will cause itching, dryness, Pinasa and dimness of vision.

\section{Various Vidalaka Yoga:}

\begin{tabular}{|c|c|c|c|}
\hline S.no. & Name & Drugs & Use \\
\hline 01. & Sarvanetra Rogahara Vidalaka & $\begin{array}{l}\text { Madhuyashthi, Gairika, Saindhava, } \\
\text { Daruharidra, Rasanjana }\end{array}$ & $\begin{array}{l}\text { All types of eye } \\
\text { disorders }\end{array}$ \\
\hline 02. & Saindhava Lodhardi Lepa & $\begin{array}{l}\text { Saindhava, Lodhra Twak, Ghrita, } \\
\text { Madhicchishta }\end{array}$ & Netra Ruja \\
\hline 03. & Arma Nashaka Vidalaka & Maricha, Kesharaja Swarasa & Arma (Pterygium) \\
\hline 04. & Gairikadi Lepa & Gairika, Lalchandana, Shunthi, Vacha & Netra Abhishyanda \\
\hline 05. & Darvyadi Rasakriya & $\begin{array}{l}\text { Darvi, Patola, Madhuka, Nimba, } \\
\text { Padmaka Utpala, Prapaundarika, , } \\
\text { Madhu }\end{array}$ & $\begin{array}{l}\text { Daha, Ashru, Raga, } \\
\text { Ruja }\end{array}$ \\
\hline 06. & Bhumyamalaki Lepa & Saindhava, Bhumyamalaki, Kanji & $\begin{array}{l}\text { Netra } \\
\text { Ruja }\end{array}$ \\
\hline 07. & Shunthi, Saindhava, Ghrita Manda & & Vataja Netra Roga ${ }^{6}$ \\
\hline 08. & Gairika, Saindhava, Madhu & & \\
\hline 09. & $\begin{array}{l}\text { Ghrita Bhrishta Haritaki \& Ghrita } \\
\text { Bhrishta Lodhra }\end{array}$ & & \\
\hline 13. & Manasiladi Lepa & $\begin{array}{l}\text { Manasila, Tagara, Ela, Saindhava } \\
\text { Lavana mixed with } \mathrm{Madhu}\end{array}$ & $\begin{array}{l}\text { In Anjana-namika after } \\
\text { Swedana Bhedana }\end{array}$ \\
\hline 14. & Chandanadi Vidalaka & $\begin{array}{l}\text { Chandana, Maricha, Ela, Swarna } \\
\text { Gairika, Patna, Rasanjana, Saindhava, } \\
\text { Madhryashti }\end{array}$ & $\begin{array}{l}\text { Vataja Abhishyanda \& } \\
\text { Adhimantha }\end{array}$ \\
\hline 15. & Daruharidra, Tuttha and Haritaki & & $\begin{array}{l}\text { Pittaja Abhishyanda \& } \\
\text { Adhimantha }\end{array}$ \\
\hline 16. & Shunthi, Rasajana, Swarna Gairika & & $\begin{array}{l}\text { Kaphaja Abhishyanda } \\
\text { \& Adhimantha }{ }^{9}\end{array}$ \\
\hline 17. & $\begin{array}{l}\text { Kushtha, Chandna, Utpala, Misi, } \\
\text { Pippali }\end{array}$ & & Netra Ruja \\
\hline 18. & Musta, Chandana, Agaru, Madhu & & $\begin{array}{l}\text { Netra Ruja, Daha, } \\
\text { Raga }\end{array}$ \\
\hline
\end{tabular}

\section{DISCUSSION}

Mode of action: It depends upon-

\section{Route of administration-}

As Vidalaka is applied over the skin. It rapidly penetrates the intact skin. Since the epidermis act as lipid barrier the solubility of the drug depends upon the lipid solubility of the contents. Whereas the dermis is freely permeable to many solutes. This helps in easy and fast absorption of drugs thus causing efficient results.

\section{Solubility and Bioavailability:}

Absorption of drug depends upon solubility and the local condition of the site of application. In Vidalaka the tissue contact time of the drug is more as compared to Ashchyotana and Seka. This increases the bioavaibility. As more the contact time of drug more is the rate of absorption and more is the effect. 


\section{Vascularity of absorbing surface:}

The absorption of drug is directly proportional to the vascularity of the applied surface. As Vidalaka is applied warm it increases the vascularity of the area hence increasing the absorption.

The drugs mixed in Vidalaka possess their own property for eg. Vidalaka prepared from Dashamoola will be Shothashamaka, Vedanahara and in the same way Vidalaka prepared from Chandanadi will be dahashamaka.

\section{Vidalaka for cosmetology-}

As Vidalaka is one of the type of Lepa Kalpana it can nourish the skin and also increase its elasticity thus preventing ageing and wrinkling below the eyes. It can also be used in eye skin tag occurring with the increasing age.

\section{According to Ayurveda-}

As it is said Srotomaya Purusha the whole body consist of Sukshma Srotasa or whole body is porous. Through this pores or channels the minute particles of drug applied in form of Vidalaka penetrates into the skin. At this stage the Upshoshana Guna of Vata Dosha contributes in the penetration and absorption of the drug. Bhrajaka Pitta present in skin is responsible for metabolism of the drug applied over the skin.

Vidalaka when mixed with Ghrita can reach into the deeper tissues of the eye as Ghrita is both hydrophillic and lipophillic in nature. Vidalaka mixed with Madhu can also reaches the deeper tissue because of its Sukshma Guna and its Yogvahi property.

\section{CONCLUSION}

As Vidalaka is an external application procedure it can be used easily. It is useful in acute eye conditions or in Amavastha of the Netra Rogas. It gives soothing effect to the eyes. And also there are lots of references of Vidalaka Prayoga in various eye disorders in Ayurvedic texts. So when used in appropriate condition in appropriate amount and for appropriate time it gives effective results.

\section{Acknowledgement: None}

\section{Conflict of Interest: None}

\section{Source of Funding: None}

\section{REFERENCES}

1. Kashinath Pandey and Gorakhnath Chaturvedi, Charak Samhita, Vidyotini hindi Vyakhya Edition- 2014, Chaukhamba Vishwabharti Publication, Chikitsasthana Chapter 26 Shloka 231.

2. Dr Brahmanand Tripathi, Sharangdhar Samhita of Acharya Sharangdhar Edited by Chaukhamba Orientalia Varanasi, 2011; $13 / 30$

3. K.P Srikanta Moorti, Astanga Sangrah Samhita by Acharya Vagbhatt, vol.1edited by Chaukhambha Orientalia, Varanasi, 6 th edition. Sutrasthana 32/4

4. K.P Srikanta Moorti, Astanga Sangrah Samhita by Acharya Vagbhatt vol.1edited by Chaukhambha Orientalia, Varanasi, 6 th edition. Sutrasthana 21/8

5. Dr Brahmanand Tripathi, Sharangdhar Samhita of Acharya Sharangdhar Edited by Chaukhamba Orientalia Varanasi, 2011; Uttartantra 13/31-37

6. Kashinath Pandey and Gorakhnath Chaturvedi, Charak Samhita, Vidyotini hindi Vyakhya Edition- 2014, Chaukhamba Vishwabharti Publication, Chikitsasthana Chapter 26 Shloka 232-236.

7. K.P Srikanta Moorti Astanga Sangrah Samhita by Acharya Vagbhatt vol.1edited by Chaukhambha Orientalia, Varanasi, 6 th edition. Uttartantra 19/3

8. K.P Srikanta Moorti Astanga Sangrah Samhita by Acharya Vagbhatt vol.1edited by Chaukhambha Orientalia, Varanasi, 6 th edition. Uttartantra 19/14

How to cite this article: Rajput SS, Mishra S, Sharma $\mathrm{R}$ et.al. A literary review on role of vidalaka in eye disorders. Int $J$ Health Sci Res. 2021; 11(6): 271-273. DOI: https://doi.org/10. 52403/ijhsr.20210640 